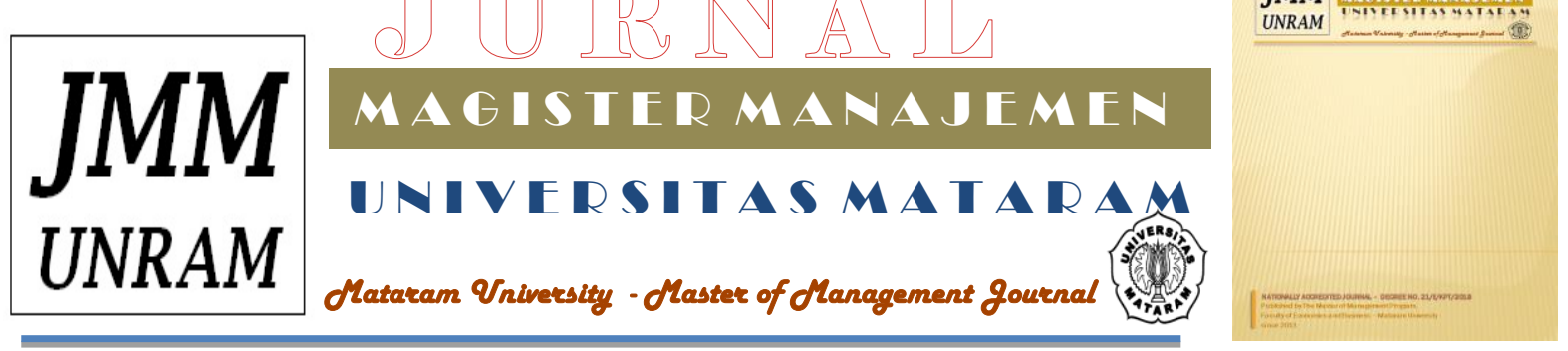

\title{
INVESTOR ASING DAN RETURN PASAR : APAKAH INVESTOR ASING MENDESTABILIZE BURSA EFEK INDONESIA
}

\section{Ni Ketut Surasni ${ }^{1}$, I Dewa Gede Bisma ${ }^{2}$, Hermanto ${ }^{3}$, Burhanudin ${ }^{4}$, Iwan Kusuma Negara ${ }^{5}$}

1,23,3,5Fakultas Ekonomi dan Bisnis, Universitas Mataram, Indonesia

\begin{tabular}{|c|c|}
\hline ARTICLE INFO & ABSTRACT \\
\hline $\begin{array}{l}\text { Keywords: } \\
\text { base-broadening, price pressure, feedback trading } \\
\text { Kata Kunci: } \\
\text { perluasan basis, tekanan harga, perdagangan } \\
\text { umpan balik. } \\
\text { How to cite: } \\
\text { Surasni, N. K., Bisma, I D G., Hermanto., } \\
\text { Burhanudin., Negara, I. K. (2019), Investor } \\
\text { Asing dan Return Pasar: Apakah Investor } \\
\text { Asing Mendestabilize Bursa Efek Indonesia. } \\
\text { JMM UNRAM, 8(1) } 73-85 \\
\text { DOI: }\end{array}$ & $\begin{array}{l}\text { The purpose of this study is to analyze the impact of the } \\
\text { presence of foreign investors on market returns on the } \\
\text { Indonesia Stock Exchange. To see the impact of foreign } \\
\text { investor trading activities, this study proposes three } \\
\text { hypotheses that will be proven. The first hypothesis is that } \\
\text { foreign investors will increase portfolio diversification or the } \\
\text { so-called base-broadening hypothesis. The second hypothesis is } \\
\text { that foreign investors will cause price pressures on stocks or } \\
\text { the price pressure hypothesis. The third hypothesis is that } \\
\text { foreign investors use certain strategies in their trading, namely } \\
\text { the feedback trading strategy. Of the } 401 \text { companies selected } 32 \\
\text { companies as samples. Furthermore, from the three hypotheses } \\
\text { proposed, the only proven hypothesis is the price pressure. } \\
\text { Thus, foreign investors can cause destabilize prices on the } \\
\text { Indonesia Stock Exchange. The destabilize implication is that } \\
\text { investors are possible to use negative feedback trading } \\
\text { strategies to make a profit. } \\
\text { Tujuan dari penelitian ini adalah untuk menganalisis } \\
\text { dampak keberadaan investor asing terhadap return pasar } \\
\text { di Bursa Efek Indonesia. Untuk melihat dampak aktivitas } \\
\text { perdagangan investor asing, penelitian ini mengajukan } \\
\text { tiga hipotesis yang akan dibuktikan. Hipotesis pertama } \\
\text { adalah investor asing akan meningkatkan diversifikasi } \\
\text { portofolio atau disebut hipotesis base-broadening. } \\
\text { Hipotesis kedua yaitu investor asing akan menyebabkan } \\
\text { tekanan harga pada saham atau disebut hipotesis price } \\
\text { pressure. Hipotesis ketiga adalah investor asing } \\
\text { menggunakan strategi tertentu didalam perdagangannya } \\
\text { yaitu strategi feedback trading. Dari } 401 \text { perusahaan } \\
\text { terpilih } 32 \text { perusahaan sebagai sampel. Selanjutnya dari } \\
\text { ketiga hipotesi yang diajukan, yang terbukti hanya } \\
\text { hipotesis price pressure. Dengan demikian maka investor } \\
\text { asing dapat menyebabkan destabilize harga di Bursa Efek } \\
\text { Indonesia. Implikasi destabilize ini adalah investor }\end{array}$ \\
\hline
\end{tabular}




\section{Jurnal Magister Manajemen Unram Vol. 8, No 1. Maret 2019 NATIONALLY ACCREDITED JOURNAL - DECREE NO. 21/E/KPT/2018}

dimungkinkan untuk menggunakan strategi negative feedback trading untuk memperoleh keuntungan.

Copyright $\odot 2019$ JMM UNRAM. All rights reserved.

\section{PENDAHULUAN}

\subsection{Latar Belakang}

Liberalisasi pasar modal di Indonesia dilakukan secara bertahap, dimulai pada tahun 1989, saat itu dikeluarkan peraturan bahwa investor asing dapat membeli dan memiliki saham dari perusahaan-perusahaan non keuangan yang terdaftar di Bursa Efek Jakarta sampai dengan maksimum 49\%. Akhirnya di tahun 1998 dikeluarkan peraturan bahwa investor asing boleh memiliki $100 \%$ saham perusahaan-perusahaan non keuangan ataupun perusahaan-perusahaan keuangan.

Ada beberapa karakteristik penting dari perdagangan asing di Indonesia. Wang (2000), menunjukkan bahwa perdagangan asing sangat menonjol di Bursa Efek Indonesia, di tahun 1996 saja nilai perdagangan asing sudah melampaui 50\% dari nilai perdagangan harian. Turn over asing juga sangat tinggi, hal ini sesuai dengan temuan Tesar dan Werner (1995) di beberapa pasar modal yang sudah maju. Selanjutnya Wang (2000) juga menunjukkan bahwa investor asing merupakan net buyer di Indonesia. Rata-rata net buyer investor asing adalah 5\% dari nilai perdagangan harian. Tingginya aktivitas perdagangan asing di Indonesia membuat penelitian tentang perilaku dan dampak investor asing di Indonesia menjadi menarik untuk dilakukan.

Keuntungan dari adanya investor asing adalah meningkatnya likuiditas dan efisiensi pasar lokal. Dalam jangka panjang, return yang diharapkan (expected return) akan menurun sebagai akibat dari pasar yang semakin terintegrasi. Keberadaan investor asing mempermudah perusahaan-perusahaan yang baru berdiri maupun perusahaanperusahaan yang sudah ada memperoleh dana. Keberadaan investor asing akan meningkatkan risk sharing. Beberapa studi yang terkait dengan liberalisasi antara lain dilakukan oleh Henry (2000), Bekaert dan Harvey (2002), Kim dan Singal (2000). Mereka menguji abnormal return sebelum dan setelah adanya liberalisasi pasar. Harga saham yang semakin meningkat setelah liberalisasi mengindikasikan adanya kenaikan permintaan sekuritas domestik dan meningkatnya akses perusahaan-perusahaan domestik memperoleh dana asing dengan cost of capital yang lebih rendah.

Keuntungan lain dari adanya investor asing adalah mereka menuntut pasar lokal memiliki hukum dan peraturan yang lebih baik. Peraturan yang sangat dituntut menyangkut kualitas maupun kuantitas informasi. Sebagai akibatnya maka pasar modal menjadi lebih transparan, alokasi sumber-sumber menjadi lebih baik dan pasar modal menjadi lebih sehat.

Namun demikian, liberalisasi pasar modal tidak hanya mendatangkan manfaat akan tetapi dapat juga mendatangkan masalah. Berbeda dengan foreign direct investment, maka investor portofolio asing menuntut agar modal mereka kembali dengan cepat sehingga hal ini akan menyebabkan aliran dana mereka mengalir dengan cepat baik aliran dana masuk (inflow) ataupun aliran dana keluar (outflow). Aliran dana yang sangat cepat ini dapat berdampak kurang baik bagi pasar modal. Aliran dana keluar pada saat krisis akan sangat merugikan. Stiglitz (1998) menyatakan bahwa negara-negara sedang berkembang sangat membutuhkan pengendalian aliran dana karena negara-negara tersebut lebih rapuh terhadap perubahan aliran dana internasional. Pasar modal yang sedang berkembang lebih rapuh terhadap guncangan krisis finansial dibandingkan dengan pasar modal yang sudah 


\section{Jurnal Magister Manajemen Unram Vol. 8, No 1. Maret 2019 NATIONALLY ACCREDITED JOURNAL - DECREE NO. 21/E/KPT/2018}

maju. Investor asing sering dianggap sebagai penyebab ketidakstabilan finansial karena aktivitas perdagangan investor asing menimbulkan aliran yang mendadak (sudden flows). Persepsi umum tentang investor asing adalah mereka seringkali merupakan spekulanspekulan dan investasi mereka dimotivasi untuk mencari keuntungan jangka pendek (Batra, 2003). Oleh karena itu maka aliran modal yang ditimbulkan oleh aktivitas perdagangan mereka bersifat mendadak. Di dalam mencari keuntungan jangka pendek, investor asing akan mengadopsi strategi-strategi perdagangan jangka pendek seperti positive feedback dan herding. Sifat perdagangan yang demikian diyakini akan menimbulkan tekanan pada harga (price pressure),sehingga pada akhirnya dapat memperburuk krisis finansial.

\subsection{Permasalahan}

Sejak meningkatnya globalisasi maka aliran modal antar negara menjadi meningkat sehingga semakin dibutuhkan kajian mengenai dampak aliran dana global tersebut bagi pasar modal. Kajian dampak liberalisasi telah banyak dilakukan pada pasar modal yang sudah maju, dan baru belakangan ini mulai diteliti dampaknya pada pasar modal yang sedang berkembang. Dalam suatu pasar dimana para agennya tidak memiliki informasi yang sama, maka perdagangan akan membawa (menyampaikan) informasi dan oleh karenanya akan menyebabkan dampak yang persistent terhadap harga sekuritas (Hasbrouck, 1991). Jika perdagangan merupakan informasi yang akan mempengaruhi harga, maka diharapkan aliran dana investor asing yang melakukan perdagangan akan mempengaruhi harga sekuritas, dengan kata lain perilaku investor asing dalam melakukan perdagangan akan memberikan dampak bagi pasar. Penelitian-penelitian sebelumnya pada umumnya menggunakan analisis level pasar, dengan kata lain transaksi asing dilihat dampaknya terhadap pasar. Akan tetapi penelitian ini menggunakan pendekatan analisis level saham atau perusahaan. Transaksi investor asing disetiap perusahaan akan dilihat dampaknya terhadap return perusahaan. Harapannya penelitian ini dapat melengkapi penelitian-penelitian sebelumnya. Penelitian ini mencoba menganalisis lebih lanjut tentang keberadaan investor asing serta dampaknya bagi Bursa Efek Indonesia. Fokus penelitian ini adalah apakah perdagangan investor asing bermanfaat atau justru mendestabilize harga saham. Dengan demikian maka yang menjadi permasalahan di dalam penelitian ini adalah dampak aliran modal asing terhadap return perusahaan.

\subsection{Tujuan Penelitian}

Tujuan penelitian ini adalah untuk mengevaluasi perilaku investor asing dan dampak aktivitasnya terhadap perusahaan-perusahaan di Bursa Efek Indonesia. Fokus penelitian ini adalah menganalisis apakah perdagangan asing tersebut dapat memberi manfaat bagi perusahaan ataukah aktivitas perdagangan asing tersebut justru mendestabilize harga saham. Secara lebih spesifik maka tujuan penelitian ini adalah: menganalisis apakah aliran modal investor asing mempengaruhi return saham.

\section{KAJIAN PUSTAKA DAN PENGEMBANGAN HIPOTESIS}

\subsection{Kajian Pustaka}

Model teoritis seleksi portofolio yang dikembangkan oleh Harry Markowitz dan James Tobin menyediakan suatu penjelasan yang positif serta kaidah-kaidah yang normatif bagi diversifikasi asset-asset yang berisiko (Levy, Sarnat, 1970). Sejak itu, ide terpenting teori portofolio adalah diversifikasi. Didasarkan pada mean dan variance maka ide teori pasar modal moderen adalah investor akan melakukan diversifikasi secara efisien. Jika 


\section{Jurnal Magister Manajemen Unram Vol. 8, No 1. Maret 2019 NATIONALLY ACCREDITED JOURNAL - DECREE NO. 21/E/KPT/2018}

semua investor memiliki akses informasi yang sama maka investor akan memilih portfolio pasar (market portfolio). Beberapa studi yang dilakukan di antara tahun 1960an dan 1970an menunjukkan bahwa investor memperoleh keuntungan dengan memiliki aset-aset global dibandingkan hanya memiliki aset-aset domestik (Grubel, 1968; Levy dan Sarnat, 1970, Solnik, 1974). Sejak itu negara-negara mulai mengurangi kendala-kendala melakukan investasi internasional (misalnya seperti kendali pemerintah terhadap aliran modal antara negara, kesulitan-kesulitan memperoleh informasi pasar modal, perbedaan aturan-aturan finansial).

Penurunan kendala-kendala tersebut menyebabkan pertumbuhan investasi antar negara semakin tinggi. Hal ini telah menimbulkan perhatian yang besar terhadap perilaku dan dampak investor asing terutama pada pasar modal yang sedang berkembang. Investor asing dipandang dapat mempengaruhi harga pasar di suatu negara sehingga aktivitas perdagangannya memperoleh perhatian yang besar (Richard,2004). Pasar yang sedang berkembang merupakan tempat yang menarik bagi investor asing untuk melakukan investasi. Dvorak (2001), menunjukkan bahwa korelasi antara return pasar sedang berkembang dengan return dunia (world return) lebih kecil jika dibandingkan dengan korelasi antara return pasar yang sudah maju dengan return dunia. Hal ini mengindikasikan bahwa pasar yang sedang berkembang menawarkan risiko sistematis yang lebih kecil dibandingkan dengan pasar yang sudah maju. Oleh karena itu maka pasar sedang berkembang menjadi tempat yang lebih menarik bagi investor asing untuk melakukan investasi karena dapat menurunkan risiko.

\subsection{Pengembangan Hipotesis}

Setidaknya ada tiga penjelasan terhadap hubungan antara aliran modal asing dengan return pasar yaitu (1)base-broadening hypothesis (2)price-pressure hypothesis (3)positive feedback strategy atau disebut juga return chasing strategy

\subsubsection{Base-Broadening}

Teori dibelakang hipotesis base-broadening, menyatakan bahwa perluasan basis investor dengan memasukkan investor asing ke dalam pasar domestik akan menyebabkan diversifikasi semakin meningkat. Peningkatan diversifikasi ini akan disertai dengan turunnya risiko karena kini risiko bukan hanya ditanggung oleh investor domestik, namun juga ditanggung bersama-sama dengan investor asing (risk sharing). Peningkatan risk sharing ini disebut base broadening effect, merupakan fondasi teoritis yang sangat penting dari keuntungan liberalisasi pasar modal.

Beberapa studi menemukan bukti adanya hipotesis base-broadening, bahwa transaksi investor internasional memiliki dampak yang positif terhadap harga saham di dalam negeri. Studi-studi tersebut antara lain, Warther (1995), menemukan bahwa terdapat hubungan antara aliran mutual fund agregat (aggregate mutual fund flows) dengan return sekuritas di pasar modal Amerika Serikat. Tesar dan Werner (1995), menemukan bahwa harga saham cenderung meningkat ketika investor internasional melakukan pembelian saham. Froot, O'Connel dan Seasholes (2001), menunjukkan bahwa kenaikan harga saham terjadi setelah investor asing membeli saham tersebut. Dengan kata lain aliran portofolio internasional (international portfolio flows) nampaknya dapat memprediksi return (Froot, Ramadorai, 2005). Dengan menggunakan data bulanan pada pasar modal Mexico maka Bohn dan Tessar (1996), menunjukkan adanya hubungan yang positif antara aliran ekuitas dengan return saham. Ananthanarayanan, Krishnamurti, Sen (2003), menggunakan model yang diajukan oleh Clark, Berko (1997) menemukan bukti yang kuat dan konsisten adanya hipotesis base-broadening pada pasar modal di India. 


\section{Jurnal Magister Manajemen Unram Vol. 8, No 1. Maret 2019 NATIONALLY ACCREDITED JOURNAL - DECREE NO. 21/E/KPT/2018}

Dari konsep teoritis dan beberapa hasil penelitian yang megindikasikan adanya base-broadening maka diajukan hipotesis sebagai berikut:

H1: Aliran modal investor asing akan meningkatkan return saham.

\subsubsection{Tekanan Harga (Price Pressure)}

Aliran investasi asing dapat mempengaruhi harga saham domestik walaupun investor asing tersebut tidak memiliki informasi. Aliran tersebut dapat didorong oleh sentimen investor asing yang tidak ada hubungannya dengan faktor fundamental. Sentimen tersebut akan menyebabkan pergerakan harga saham domestik, baik naik ataupun turun. Harga akan berbalik (reversal) setelah tekanan mereda. Oleh karena itu price pressure ini disebut dampak yang temporer. Studi-studi antara lain Frankel dan Froot (1987), De Long, Shleifer, Summers dan Waldmann (1990), Barberies dan Shleifer (2003), menyatakan bahwa polapola perdagangan suatu kelompok investor (misalnya pola positive feedback) seringkali mendorong likuiditas suatu asset. Hal ini akan mendorong harga saham menjauh dari nilai fundamentalnya. Akan tetapi sebagaimana peningkatan likuiditasnya maka kadangkala dampak ini juga akan segera hilang sehingga harga saham akan berbalik kembali menuju nilai fundamentalnya. Bekaert, Harvey dan Lumsdaine (2002) menemukan bukti bahwa kejutan (shock) positif aliran (flows) menyebabkan peningkatan harga dalam jangka waktu pendek (short term). Ananthanarayanan, Krishnamurti, Sen (2003), menemukan bukti yang mendukung hipotesis price pressure di pasar modal India.

Dari hasil beberapa studi diatas maka diajukan hipotesis sebagai berikut:

\section{H2: Aliran modal asing akan memberikan tekanan pada harga saham.}

\subsubsection{Positive Feedback Trader}

Secara umum ada dua jenis investor di pasar modal yaitu: (1) investor yang memaksimumkan expected utility yang disebut smart money dan (2) investor trend chasing atau disebut investor feedback. Investor kelompok ke dua diasumsikan akan mengikuti strategi perdagangan momentum yaitu, melakukan pembelian ketika harga saham naik dan melakukan penjualan ketika harga saham menurun.

Brennan dan Cao (1997), mengembangkan suatu model aliran investasi portofolio ekuitas internasional berdasarkan pada perbedaan informasi yang dimiliki oleh investor asing dan investor domestik. Model tersebut memprediksi bahwa jika investor domestik dan asing memiliki informasi yang berbeda maka aliran portofolio merupakan fungsi linear dari return kontemporanus (contemporaneous return). Jika investor memiliki informasi yang lebih baik dibandingkan dengan investor asing maka koefisien return pasar dalam negeri adalah positif.

Beberapa hasil studi sebelumnya mengindikasikan bahwa investor asing mengikuti strategi positive feedback trading. Barberis, Shleifer, Vishny (1998), Daniel, Hirshleifer, Subrahmanyam (1998), Hong, Stein (1999), Jegadeesh, Titman (1993 dan 2001) menemukan short-term return continuation dan menemukan bahwa strategi positive feedback trading menghasilkan keuntungan yang signifikan dalam jangka pendek (short-term). Studi-studi lain juga dilakukan oleh, Bohn, Tesar (1996), Froot, O'Connel, Seashole (2001), Froot, Ramodarai (2001), menemukan bahwa return yang tinggi akan menyebabkan aliran dana masuk sementara return yang rendah akan menyebabkan aliran dana keluar. Dari beberapa temuan di atas dapat diajukan hipotesis sebagai berikut

H3: Return saham akan mempengaruhi aliran modal asing. 


\section{Jurnal Magister Manajemen Unram Vol. 8, No 1. Maret 2019 NATIONALLY ACCREDITED JOURNAL - DECREE NO. 21/E/KPT/2018}

\section{METODE PENELITIAN}

\subsection{Populasi dan Sampel}

Populasi dalam penelitian ini adalah seluruh perusahaan yang terdaftar di Bursa Efek Indonesia . Pemilihan sampel ditentukan secara purposive sampling dengan persyaratan sebagai berikut:

1. Perusahaan setidaknya sudah terdaftar tahun 2016

2. Memiliki data tentang transaksi investor asing

3. Setidaknya terdapat transaksi asing setiap bulannya

4. Dipilih 35 saham yang memiliki transaksi asing bulanan tertinggi

\subsection{Data dan Sumber Data}

\subsubsection{Data yang dibutuhkan dalam penelitian ini meliputi}

1. Return saham bulanan

2. Aliran Bersih (Net Flow) investor asing (selisih antara transaksi beli dan jual) di masingmasing saham setiap bulan

\subsubsection{Sumber Data}

Data merupakan data sekunder dan diperoleh melalui internet.

\subsection{Pengukuran Variabel}

3.3.1. Pengukuran Return saham

Return saham dihitung menggunakan rumus sebagai berikut:

$\mathrm{R}_{\mathrm{t}}=\frac{\mathrm{P}_{\mathrm{t}}-P_{t-1}}{P_{t-1}}$

$\mathrm{R}_{\mathrm{t}}=$ return saham pada periode ke $\mathrm{t}$

$P_{t}=$ harga saham pada periode ke $t$

$\mathrm{P}_{\mathrm{t}-1}=$ harga saham pada periode ke $\mathrm{t}-1$

\subsubsection{Aliran Modal Asing}

Agar supaya aliran dana bersih (netflows) bisa dibandingkan maka dilakukan standarisasi atau dilakukan skala dengan kapitalisasi pasar masing-masing perusahaan periode sebelumnya (Ananthanarayanan, Krishnamurti dan Sen, 2003) sehingga untuk aliran masuk dan aliran keluar harian menjadi:

$$
\begin{array}{ll}
\mathrm{Net}=\frac{\mathrm{FB}_{\mathrm{t}}-}{\mathrm{FS}_{t}} & \\
\mathrm{FS}_{\mathrm{t}} & =\text { transaksi jual investor asing }_{\mathrm{t}-1} \\
\mathrm{FB}_{\mathrm{t}} & =\text { transaksi beli investor asing } \\
\mathrm{Net} & =\text { aliran modal investor asing bersih } \\
\text { MarketCap } \mathrm{t}-1 & =\text { kapitalisasi pasar dari saham periode sebelumnya }
\end{array}
$$

\subsubsection{Expected dan Unexpected Flows}

Aliran modal akan dibagi menjadi dua yaitu yang dapat diekspektasi (expected flows) dan yang tidak dapat diekspektasi (unexpected flows). Alasan dari pembagian ini adalah karena expected flows mestinya tidak akan mempengaruhi return karena expected flows sudah diantisipasi oleh pasar terlebih dahulu. Suatu pasar yang efisien tidak akan bereaksi terhadap expected flows. Unexpected flows akan membawa suatu shock atau surprise dan pasar akan bereaksi terhadap shock tersebut. Untuk menentukan expected flows akan 


\section{Jurnal Magister Manajemen Unram Vol. 8, No 1. Maret 2019 NATIONALLY ACCREDITED JOURNAL - DECREE NO. 21/E/KPT/2018}

digunakan nilai flows rata-rata, sedangkan unanticipated atau unexpected flows diperoleh dengan mengurangkan expected flows dengan real flows.

\subsection{Prosedur Analisis}

\subsubsection{Menguji Hipotesis Base-broadening}

Hubungan antara return dan aliran modal dapat dijelaskan dengan menggunakan hipotesis base-broadening sebagaimana dipaparkan pada tinjauan pustaka. Untuk menguji hipotesis base-broadening maka digunakan model dasar sebagai berikut:

$$
R_{t}=\beta_{0}+\beta_{1} E_{t}\left[\frac{\text { NetFlow }_{t}}{\text { Market } \text { Cap }_{\mathrm{t}-1}}\right]+\beta_{2} U_{t}\left[\frac{\text { NetFlow }_{t}}{\text { Market } \text { Cap }_{\mathrm{t}-1}}\right]
$$

Keterangan:

$\mathrm{E}_{\mathrm{t}}\left[\right.$ Net Flow $_{\mathrm{t}} /$ Market Cap $\left._{\mathrm{t}-1}\right]=$ expected net flow pada peride $\mathrm{t}$

$\mathrm{U}_{\mathrm{t}}\left[\right.$ Net Flow $_{\mathrm{t}} /$ Market Cap $\left._{\mathrm{t}-1}\right]=$ unexpected net flow pada peride $\mathrm{t}$

Syarat terjadi base-broadening adalah

$\beta_{1} \geq 0, \quad \beta_{2}>0$

\subsubsection{Menguji Hipotesis Price Pressure}

Penjelasan ke dua hubungan antara return dengan aliran modal adalah hipotesis price pressure. Ketika investor asing melakukan investasi maka demand akan meningkat. Peningkatan demand ini akan menggerakkan harga saham menjauh dari fundamentalnya. Namun dorongan demand ini bersifat temporer dan harga akan kembali kepada fundamentalnya. Untuk menguji hipotesis price pressure digunakan model sebagai berikut:

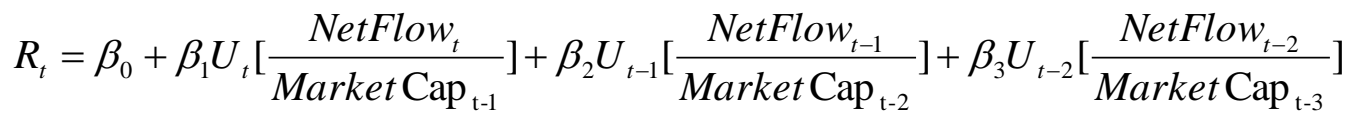

Keterangan:

$\mathrm{R}_{\mathrm{t}} \quad=$ return saham pada periode $\mathrm{t}$

$\mathrm{U}_{\mathrm{t}}\left[\right.$ Net Flow $\mathrm{t} /$ Market Cap $\left.\mathrm{p}_{\mathrm{t}-1}\right]=$ Unexpected net flow pada periode $\mathrm{t}$ yang diskala dengan kapitalisasi pasar saham periode $\mathrm{t}-1$

$\mathrm{H}_{0}: \beta_{2}, \beta_{3}=0$ dan $\mathrm{H}_{\mathrm{a}}: \beta_{2}, \beta_{3}<0$ Jika price pressure terjadi maka koefisien lag unexpected flow adalah negatif dan signifikan.

Jika price pressure terbukti maka investor asing terbukti mendestabilize pasar.

\subsubsection{Menguji Hipotesis Feedback Trader}

Hipotesis lain yang dapat digunakan untuk menjelaskan hubungan aliran modal dan return adalah hipotesis feedback trader. Model untuk menguji hipotesis feedback trader adalah:

$$
\mathrm{U}_{\mathrm{t}}\left[\frac{\text { NetFlow }_{t}}{\text { Market } \text { Cap }_{\mathrm{t}-1}}\right]=\beta_{0}+\beta_{1} R_{t}+\beta_{2} R_{t-1}+\beta_{3} R_{t-2}
$$

Keterangan:

$\mathrm{U}_{\mathrm{t}}\left[\right.$ Net Flow $_{\mathrm{t}} /$ Market Cap $\left._{\mathrm{i}, \mathrm{t}-1}\right]=$ Unexpected net flow pada periode $\mathrm{t}$ yang diskala dengan kapitalisasi pasar saham periode $\mathrm{t}-1$

Ada dua alternatif yang akan diperoleh dari hasil model tersebut yaitu:

Alternatif $1: \mathrm{H}_{0}: \beta_{2}, \beta_{3}=0$ dan $\mathrm{H}_{\mathrm{a}}: \beta_{2,}, \beta_{3}>0$

Alternatif $2: \mathrm{H}_{0}: \beta_{2}, \beta_{3}=0$ dan $\mathrm{H}_{\mathrm{a}}: \beta_{2}, \beta_{3}<0$

Jika alternatif pertama terjadi maka investor asing mengikuti strategi perdagangan positive feedback trading, sebaliknya jika alternatif kedua terjadi maka investor asing mengikuti strategi perdagangan negative feedback trading. 


\section{Jurnal Magister Manajemen Unram Vol. 8, No 1. Maret 2019 NATIONALLY ACCREDITED JOURNAL - DECREE NO. 21/E/KPT/2018}

\section{HASIL ANALISIS}

\subsection{Deskripsi Data}

Pada bagian ini akan dipaparkan deskripsi data tentang volume transaksi beli (buy atau foreign inflows) dan volume transaksi jual (sell atau foreign outflows) serta transaksi bersih (foreign netflows) yang diperoleh, yang dapat dilihat pada Tabel 4.1 berikut:

Tabel 4.1

Deskripsi Data Foreign Inflows, Foreign Outflows dan Foreign Netflows di Bursa Efek Indonesia

\begin{tabular}{|l|r|r|r|r|r|}
\hline & N & Minimum & Maximum & \multicolumn{1}{c|}{ Mean } & \multicolumn{1}{c|}{$\begin{array}{c}\text { Std. } \\
\text { Deviation }\end{array}$} \\
\hline Ri & 384 & -.4036 & 8.6296 & .039513 & .4852787 \\
Ri_1 & 384 & -.4036 & 8.6296 & .042186 & .4855453 \\
Ri_2 & 384 & -.4036 & 8.6296 & .039440 & .4864775 \\
Exp_t & 384 & -17.2977 & 95.1723 & -.792928 & 6.4701519 \\
Ui & 384 & -116.5178 & 78.6573 & -.229381 & 12.9074789 \\
Ui_1 & 384 & -116.5178 & 78.6573 & -.356718 & 13.8617618 \\
Ui_2 & 384 & -116.5178 & 78.6573 & -.394624 & 14.4899951 \\
Buy & 384 & 130500 & 3417581000 & 211450286.98 & 295163170.74 \\
& & & & & 6 \\
Sell & 384 & 150000 & 3390421600 & 214113400.78 & 292329876.92 \\
& & & & & 5 \\
Net & 384 & -745942500 & 536137300 & -2663113.80 & 107771815.20 \\
Valid N & & & & & 4 \\
(listwise) & 384 & & & & \\
\hline
\end{tabular}

Keterangan:

Buy : Merupakan volume beli investor asing atau foreign inflows

Sell : Merupakan volume jual investor asing atau foreign outflows

Net :Merupakan transaksi bersih infestor asing atau foreign netflows

$\mathrm{R}_{\mathrm{i}} \quad$ : Return saham bulanan pada periode $\mathrm{t}$

$\mathrm{R}_{\mathrm{i} \_1} \quad$ : Return saham bulanan pada periode $\mathrm{t}-1$

$\mathrm{R}_{\mathrm{i} \_2} \quad$ : Return saham bulanan pada periode $\mathrm{t}-2$

Exp_t : Expected Flows bulanan dibagi kapitalisasi saham

$\mathrm{U}_{\mathrm{i}} \quad$ : Unexpected Flows bulanan dibagi kapitalisasi saham pada periode $\mathrm{t}$

$\mathrm{U}_{\mathrm{i}_{1} 1} \quad$ : Unexpected Flows bulanan dibagi kapitalisasi saham pada periode $\mathrm{t}-1$

$\mathrm{U}_{\mathrm{i} \_2} \quad$ : Unexpected Flows bulanan dibagi kapitalisasi saham pada periode $\mathrm{t}-2$

Berdasarkan Tabel 4.1 dapat dilihat bahwa foreign netflows bertanda negatif. Hal ini disebabkan karena investor asing lebih banyak melakukan aksi jual saham dibandingkan dengan aksi beli saham. Dengan kata lain, pada tahun 2017, di Bursa Efek Indonesia telah terjadi aliran modal asing keluar. Ini suatu indikasi yang kurang baik karena dapat menyebabkan berkurangnya sumber modal internasional bagi perusahaan-perusahaan yang terdaftar di Bursa Efek Indonesia. Aliran modal-keluar tersebut dialokasikan pada investasi-investasi yang lebih menguntungkan. Besar kemungkinannya hal ini berkaitan dengan kebijakan di negara asal (foreign country) yang lebih menguntungkan. Hal inilah sebenarnya yang menjadi kelemahan foreign flows karena sering menimbulkan sudden 


\section{Jurnal Magister Manajemen Unram Vol. 8, No 1. Maret 2019 NATIONALLY ACCREDITED JOURNAL - DECREE NO. 21/E/KPT/2018}

flows, yang jika dalam jumlah yang besar dapat menimbulkan permasalahan pada pasar domestik.

\subsection{Pengujian Hipotesis Base-Broadening}

Portofolio internasional menyatakan bahwa diversifikasi akan lebih menguntungkan jika melakukannya antar pasar modal di negara yang berbeda. Hal ini disebabkan karena pasar modal diberbagai negara sering tidak terintegrasi. Ketika di suatu pasar modal terdapat investor-investor dari berbagai negara maka timbul perluasan base (dasar) investor. Hipotesis base broadening ini mengacu pada risk sharing yang akan terjadi ketika investor asing bersama-sama dengan investor domestik bertransaksi di suatu pasar modal. Risiko yang tadinya hanya ditanggung oleh investor domestik, sekarang ditanggung bersamasama dengan investor asing. Ini merupakan dampak baik dari keberadaan investor asing, di suatu pasar domestik.

Hasil pengolahan data menunjukkan hasil sebagaimana tabel 4.2 berikut

Tabel 4.2

Hasil Regresi Return Saham Terhadap Expected dan Unexpected Net Flows

\begin{tabular}{|c|c|c|c|c|c|c|}
\hline \multirow{2}{*}{\multicolumn{2}{|c|}{ Model }} & \multicolumn{2}{|c|}{$\begin{array}{l}\text { Unstandardized } \\
\text { Coefficients }\end{array}$} & $\begin{array}{c}\text { Standardized } \\
\text { Coefficients }\end{array}$ & \multirow[t]{2}{*}{$\mathrm{t}$} & \multirow[t]{2}{*}{ Sig. } \\
\hline & & B & Std. Error & Beta & & \\
\hline \multirow{3}{*}{1} & $\begin{array}{l}\text { (Constant } \\
\text { ) }\end{array}$ & .075 & .018 & & 4.268 & .000 \\
\hline & Exp_t & .047 & .003 & .624 & 16.216 & .000 \\
\hline & Ui & -.007 & .001 & -.187 & -4.871 & .000 \\
\hline
\end{tabular}

a. Dependent Variable: Ri

Tabel tersebut menunjukkan bahwa baik expected maupun unexpected flows berpengaruh signifikan terhadap return saham (tingkat signifikansi $<0,05$ ). Hal ini menunjukkan bahwa netflows berpengaruh terhadap return saham. Harga saham berubah karena perubahan netflows. Berbeda dengan yang diharapkan, ternyata selain unexpected netflows maka expected netflows juga berpengaruh terhadap return saham. Dengan demikian maka investor bereaksi terhadap unexpected netflows dan bereaksi juga terhadap expected netflows. Reaksi investor berbeda terhadap expected dan unexpected netflows. Positif terhadap expected netflows dan negative terhadap unexpected netflows.

Hipotesis Base-Broadening terbukti jika koefisien regresi Exp_t $\geq 0$ dan koefisien regresi $U_{i}>0$. Berdasarkan tabel 4.2 tersebut, koefisien regresi unexpected flows bertanda negative (hipotesis base-broadening meminta tanda positif). Hipotesis base- broadening tidak terbukti, hal ini disebabkan karena netflows dari investor asing adalah negative (sebagaimana yang ditunjukkan pada Tabel 4.1). Tanda negative menunjukkan bahwa pada tahun amatan, investor asing melakukan aksi jual lebih besar dari pada aksi beli. Ketika investor asing lebih banyak melepas sahamnya daripada membeli saham maka investor akan memberikan reaksi negative dengan menawar harga lebih murah. Dengan demikian maka reaksi terhadap aksi jual asing menyebabkan harga turun dan selanjutnya diikuti oleh return negative. Ketika investor asing meninggalkan pasar (yang direpresentasikan dengan aksi jual yang lebih besar daripada aksi beli), maka investor-base menjadi berkurang, sehingga risk sharing tidak dapat dilakukan lagi bersama dengan investor asing. Tidak ada lagi keuntungan yang diperoleh dari keberadaan investor asing karena telah meninggalkan pasar. Walaupun hipotesis base-broadening tidak terbukti

jmm.unram.ac.id 


\section{Jurnal Magister Manajemen Unram Vol. 8, No 1. Maret 2019 NATIONALLY ACCREDITED JOURNAL - DECREE NO. 21/E/KPT/2018}

namun reaksi investor sesuai dengan harapan. Dengan demikian maka investor asing tidak mampu meningkatkan diversifikasi portofolio.

\subsection{Pengujian Hipotesis Price Pressure}

Selain berdampak positif, aktivitas perdagangan investor asing juga dapat memberikan dampak negative. Aktivitas perdagangan asing dapat membuat harga saham menjauh dari nilai fundamentalnya. Aktivitas asing dapat memberi tekanan pada harga saham sehingga harga saham menjauh dari fundamentalnya. Hal ini dapat disebabkan karena sentimen investor asing. Jika investor asing mampu memberi tekanan pada harga maka investor asing akan mendestabilize pasar.

Hipotesis ini dapat juga disebut price reversal. Investor bereaksi terhadap keberadaan investor asing (disini direpresentasikan dengan foreign netflows), tapi reaksi ini bersifat berlebihan (overreaction), harga menjauh dari nilai fundamentalnya. Dengan demikian setelah reaksi terjadi, biasanya diikuti dengan regret (penyesalan), dan akhirnya harga akan kembali ke nilai fundamentalnya, atau dengan kata lain akan diikuti dengan price reversal (pembalikan harga). Hasil olahan data untuk pengujian hipotesis price pressure ditunjukkan oleh Tabel 4.3 berikut.

Tabel 4.3

Hasil Regresi Return Saham Terhadap Unexpected Net Flows Periode t, Unexpected Net Flows Periode t-1 dan Unexpected Net Flows Periode t-2

\begin{tabular}{|c|c|c|c|c|c|c|}
\hline \multirow{2}{*}{\multicolumn{2}{|c|}{ Model }} & \multicolumn{2}{|c|}{$\begin{array}{c}\text { Unstandardized } \\
\text { Coefficients }\end{array}$} & \multirow{2}{*}{$\begin{array}{c}\text { Standardized } \\
\text { Coefficients } \\
\text { Beta } \\
\end{array}$} & \multirow[t]{2}{*}{$\mathrm{t}$} & \multirow[t]{2}{*}{ Sig. } \\
\hline & & B & Std. Error & & & \\
\hline \multirow{4}{*}{1} & (Constant & .032 & .021 & & 1.481 & .139 \\
\hline & $\mathrm{Ui}$ & -.013 & .002 & -.341 & -7.555 & .000 \\
\hline & Ui_1 & -.007 & .002 & -.191 & -3.993 & .000 \\
\hline & Ui_2 & -.007 & .002 & -.202 & -4.309 & .000 \\
\hline
\end{tabular}

a. Dependent Variable: Ri

Hipotesis price pressure akan terbukti jika koefisien regresi unexpected flows periode $t-1$ maupun unexpected flows $\mathrm{t}-2$ bertanda negative. Tabel 4.4 membuktikan bahwa investor asing menyebabkan tekanan harga pada pasar, dengan kata lain hipotesis price pressure terbukti. Investor asing menyebabkan harga menjauh dari nilai fundamentalnya.

\subsection{Pengujian Hipotesis Feedback Trader}

Investor asing didalam melakukan perdagangan sering menggunakan strategi tertentu. Karena diasumsikan bahwa investor asing sering memiliki informasi yang lebih sedikit daripada investor domestik, maka investor asing akan cenderung bertransaksi mengikuti arah pasar. Strategi ini sering disebut strategi feedback trading atau trend chasing.

Hasil olahan data untuk membuktikan hipotesis feedback trader ini ditunjukkan oleh Tabel 4.4 
Tabel 4.4

Hasil Regresi Unexpected Net Flows Terhadap Return Periode t, Return Periode t-1 dan Return Periode t-2

\begin{tabular}{|c|c|c|c|c|c|c|}
\hline \multirow{2}{*}{\multicolumn{2}{|c|}{ Model }} & \multicolumn{2}{|c|}{$\begin{array}{l}\text { Unstandardized } \\
\text { Coefficients }\end{array}$} & \multirow{2}{*}{$\begin{array}{c}\text { Standardized } \\
\text { Coefficients }\end{array}$} & \multirow[t]{2}{*}{$t$} & \multirow[t]{2}{*}{ Sig. } \\
\hline & & B & Std. Error & & & \\
\hline \multirow{4}{*}{1} & (Constant & .209 & .609 & & .343 & .732 \\
\hline & $\mathrm{Ri}$ & -10.942 & 1.244 & -.411 & -8.800 & .000 \\
\hline & Ri_1 & -.307 & 1.243 & -.012 & -.247 & .805 \\
\hline & Ri_2 & .175 & 1.240 & .007 & .141 & .888 \\
\hline
\end{tabular}

a. Dependent Variable: Ui

Tabel 4.4 menunjukkan tidak ada koefisien regresi yang signifikan. Dengan demikian investor asing tidak menggunakan strategi Feedback Trading maupun Negative Feedback Trading. Namun demikian jika melihat arah dari koefisien regresi yang bertanda negative (walaupun tidak signifikan), maka kemungkinan investor asing lebih cenderung menggunakan strategi Negative Feedback Trading atau disebut juga strategi Contrarian, melakukan aksi beli saat harga saham turun dan melakukan aksi jual ketika harga naik.

\section{KESIMPULAN, SARAN DAN IMPLIKASI}

Bab ini memaparkan keimpulan hasil penelitian serta saran dan implikasi. Pertama-tama akan diuraikan kesimpulan hasil penelitian, kemudian diuraikan saran untuk penelitian selanjutnya dan akhirnya akan diuraikan apa implikasi dari temuan penelitian ini.

\subsection{Kesimpulan}

Penelitian ini bertujuan untuk menganalisis dampak perdagangan asing terhadap pasar. Dampak ini dilihat dari (1) apakah investor asing mampu meningkatkan diversifikasi portofolio atau disebut hipotesis base-broadening,(2) apakah investor asing menyebabkan tekanan pada harga atau disebut hipotesis price pressure dan (3) apakah investor asing menggunakan strategi perdagangan feedback trading.

Dari hasil analisis diperoleh kesimpulan sebagai berikut:

1. Investor asing tidak mampu meningkatkan diversifikasi portofolio pasar atau hipotesis Base-Broadening tidak terbukti pada periode penelitian (tahun 2017).

2. Investor asing menyebabkan terjadi tekanan pada harga atau hipotesis Price Pressure terbukti atau investor asing mendestabilize harga saham pada periode penelitian (tahun 2017).

3. Investor asing tidak menggunakan strategi tertentu didalam melakukan perdagangan, namun cenderung menggunakan Negative Feedback Trading pada periode penelitian (tahun 2017).

\subsection{Saran}

Saran untuk penelitian selanjutnya adalah dimungkinkan menggunakan periode harian (dalam penelitian ini menggunakan periode bulanan). Hal ini didasarkan pada pertimbangan bahwa ada kemungkinan hasil yang berbeda untuk jangka pendek (harian). Berbagai pemilihan periode amatan ini dapat berfungsi sebagai robustness hasil penelitian mengenai dampak investor asing. 


\section{Jurnal Magister Manajemen Unram Vol. 8, No 1. Maret 2019 NATIONALLY ACCREDITED JOURNAL - DECREE NO. 21/E/KPT/2018}

\subsection{Implikasi}

Penelitian ini membuktikan keberadaan tekanan harga yang disebabkan oleh perdagangan investor asing. Dengan kata lain investor asing mendestabilize harga saham. Jika hal ini terjadi maka harga menjauh dari fundamental. Tekanan harga ini akan menyebabkan harga berbalik kembali menuju keseimbangan sebelumnya atau disebut juga price reversal. Keadaan ini akan menguntungkan bagi investor yang menggunakan strategi perdagangan contrarian. Membeli ketika harga turun dan menjual ketika harga naik.

\section{DAFTAR PUSTAKA}

Barberis, N., and Shleifer, A. (1998), A Model of Investor Sentiment, Journal of Financial Economics 49, 307-343

Barberis, N., and Shleifer, A (2003), Style Investing, Journal of Financial Economics, 68,2, 161-199

Batra, A., (2003), The Dynamics of Foreign Portfolio Inflows and Equity Returns in India, Working Paper No. 109

Bekaert, G, and Harvey,C.R, (2000), Foreign Speculators and Emerging Equity Markets, Journal of Finance 55,p.565-613

Bekaert, G, and Harvey,C.R, (2002), Research in Emerging Markets Finance: Looking to The Future, Working Paper

Bekaert, G, Harvey,C.R, dan R. L. Lumsdaine, (2002), The Dynamics of Emerging Market Equity Flows, Journal of International Money and Finance 21, 295-350

Bohn, H., and Tesar, L., (1996), US Equity Investment in Foreign Markets: Portfolio Rebalancing or Return Chasing? The American Economic Review 86, 77-81

Choe, Hyuk, Bong-Chan Kho, Rene M. Stulz, (1999), Do Foreign Investor Destabilize Stock Markets? The Korean Experience in 1997, Journal of Financial Economics, 54,227-264

Daniel, K., Hirshleifer, D., Subrahmanyam, A., (1998), Investor Pshychology and Security Market Under and Overreaction, Journal of Finance 53, 1839-1886

DeLong, et, al. (1990), Noise Trader Risk in Financial Markets, Journal of Political Economy, 98, 703-738

Dvorak, T., (2005), Do Domestic Investors Have an Information Advantage? Evidence From Indonesia, Journal of Finance, Forthcoming

Frankel, J, and Froot, K. A. (1987), Using Survey Data to Test Standard Propositions Regarding Exchange Rate Expectations, American Economic Review 77, 133-153

Froot, K., O'Connel, P., Seasholes, M. S. (2001), The Portfolio Flows of International Investors, Journal of Financial Economics 59, 151-193

Froot, K., and Ramodarai, T., (2001), The Information Content of International Portfolio Flows, Working Paper

Griffin, J. M, et al. (2004), Daily Cross-Border Equity Flows, Pushed or Pulled?, Review of Economics and Statistics, 86(3),641-657

Grubel, H.G, (1968), Internationally Diversified Portfolios, The American Economic Review $58,1299-1314$

Henry, P.B, (2000), Stock Market Liberalization, Economic Reform, and Emerging Market Equity Prices, The Journal of Finance, 55, 529-564

Hong, H., and Stein, J. C. (1999), A Unified Theory of Underreaction, Momentum Trading and Overreaction I Asset Markets, Journal of Finance 54, 2143-2184

Jegadeesh, N., and Titman, S. (1993), Return to Buying Winners and Selleng Losers for Stock Market Efficiency, Journal of Finance 48, 65-91 
Jegadeesh, N., and Titman, S. (2001), Profitability of Momentum Strategies: An Evaluation of Alternative Explanations, Journal of Finance 56, 699-720

Kang, J. K, and Stulz, R. M., (1997), Why is There a Home Bias? An Analysis of Foreign Portfolio Equity Ownership in Japan, Journal of Financial Economics, 46, 2-18

Kim, E.H, and Singal, V, (2000), Stock Market Openings: Experience of Emerging Economics, Journal of Business 73, p.25-66

Levy, H., and Sarnat, M., (1970), International Diversification of Investment Portfolios, The American Economic Review 668-675

Richard, A., (2004), Big Fish in Small Ponds: The Trading Behavior and Price Impack of Foreign Investors in Asian Emerging Equity Markets, Research Discusion Paper Economic Analysis Department Reserve Bank of Australia

Stiglitz, J, (1998), Boats, Planes and Capital Flows, Financial Times

Solnik, B. H, (1974), Why Not Diversify Internationally Rather Than Domestically?, Financial Analyst Journal 30, 91-135

Tesar, L, and Werner, I. M., (1995), Home Bias and High Turnover, Journal of International Money and Finance, 14, 467-492

Wang, J., Foreign Trading and Market Volatility in Indonesia, (2000), Working Paper

Warther, V.A, (1995), Aggregate Mutual Fund Flows and Security Returns, Journal of Financial Economics 39, p. 209-235 